\title{
Suvremeni informacijski i komunikacijski alati u provođenju nastave stranoga jezika na daljinu
}

\author{
Tanja Đurić \\ tanja.duric@skole.hr \\ Osnovna škola Gračani, Zagreb
}

Odgojno-obrazovni sustav u Republici Hrvatskoj u zadnjih je deset godina na značajnoj digitalnoj prekretnici. Projekti poput CARNET-ova projekta Škole 2.0. i reforma u odgojno-obrazovnom sustavu Škola za život začetnici su te prekretnice. Najznačajnija promjena zahvatila je školsku godinu 2019./2020. zbog pandemije koronavirusa i takozvanoga lockdowna, tj. potpunoga prekida aktivnosti, a promjena uključuje školu na daljinu. Pokretanje škole na daljinu navelo je odgojno-obrazovne djelatnike i učenike na aktivno sudjelovanje u izradi i uporabi digitalnih nastavnih sadržaja, a korištenje suvremenih informacijskih alata postalo je neizbježno u nastavnome procesu. Cilj je rada dati kratki pregled suvremenih informacijskih alata korištenih u nastavi na daljinu te istražiti koji su od njih najčešće korišteni u nastavi stranih jezika na daljinu u osnovnoj školi. Cilj je i istražiti stavove nastavnika stranih jezika u osnovnim školama o ostvarenosti ishoda učenja i jezičnih vještina pomoću suvremenih informacijskih alata u nastavi stranoga jezika te koje su prednosti, a koji nedostaci s kojima su se nastavnici suočili za vrijeme nastave na daljinu. Metodologija istraživanja uključuje upitnik od 14 pitanja na koja su odgovorila 58 ispitanika, a rezultati su obrađeni kombinacijom kvalitativne i kvantitativne analize. Rezultati ukazuju na uspješnost provedbe nastave stranih jezika na daljinu u danim okolnostima te raznovrsnost suvremenih informacijskih alata korištenih u nastavi na daljinu. Rezultati također ukazuju i na određene nedostatke nastave na daljinu te preporuke za unaprjeđenje nastave na daljinu.

Ključne riječi: suvremeni informacijski alati, strani jezici, osnovna škola, nastava na daljinu. 


\section{UVOD}

Informacijsko-komunikacijska tehnologija (IKT) postala je neizostavan dio ljudske svakodnevice, prisutna je u gotovo svakome području ljudskoga djelovanja, između ostaloga i obrazovanja. Današnji učenici pripadaju $Z$ generaciji (još i fejs ili phone generacija), generaciji koja odrasta uz moderne tehnologije i društvene medije i ne može zamisliti svoj život bez njihova korištenja (Betts, Gomez, Mawhinney, 2019). Neki od razloga sve učestalijega korištenja tehnologije u obrazovanju su: osobitost generacije $\mathrm{Z}$, školska reforma, nastojanje da se obrazovanje modernizira i mijenja u skladu s modernim dobom, novonastale situacije uzrokovane epidemijom koronavirusa ${ }^{1}$ i privremenim prestankom poučavanja uz fizičku prisutnost učenika i nastavnika.

Pandemija koronavirusa od sredine ožujka do sredine lipnja 2020. uzrokovala je zatvaranje škola diljem svijeta te je preko 1,5 milijarde učenika i 63 milijuna učitelja bilo primorano učiti i raditi putem nastave na daljinu preko različitih digitalnih usluga i platformi (Google Classroom, MS Teams, Zoom i drugi) (Burns, 2020). U svijetu se pojavila veća potreba za virtualnim konferencijama, jezičnim aplikacijama, edukacijskim softverima i slično. Mnoge su digitalne platforme ponudile besplatan pristup njihovu korištenju za vrijeme pandemije. Tako je u samome žarištu u Kini, u Wuhanu, korištena digitalna platforma Tencent classroom. Europske zemlje su također koristile nacionalne digitalne platforme, npr. u Italiji je korištena platforma La Scuola del Futuro, Oggi („The School of the Future, Today”), u Irskoj Ireland's Scoilnet („Schoolnet”), u Francuskoj France's Ma classe à la maison („My Class at Home”)2. Većina je nastavnih sati u ovim zemljama uključivala sažete pisane lekcije i domaću zadaću preko digitalnih platformi, dok su u manjem dijelu učitelji koristili audio i videopozive s učenicima. Neke su zemlje imale i dodatni televizijski prijenos lekcija, poput Hrvatske („Škola na trećem“), Francuske („Nation Apprenante (“Learning Nation“) i drugih zemalja. U Estoniji je razvijen e-Koolikott („e-Schoolbag”), nacionalna digitalna knjižnica koja sadrži preko 20000 obrazovnih sadržaja pripremljenih za učitelje i kao podrška u unaprjeđivanju digitalne pismenosti i kako poučavati nastavne sadržaje na daljinu (Burns, 2020). Većinu europ-

\footnotetext{
${ }^{1}$ Službeni naziv za koronavirus je SARS-CoV-2 (COVID-19).

2 https://eacea.ec.europa.eu/national-policies/eurydice/content/covid-19-france-support-given-teachersduring-pandemic_en (Pristupljeno 9. 4. 2021.)

https://www.scoilnet.ie/go-to-primary/stem/ (Pristupljeno 9. 4. 2021.)
} 
skih zemalja povezuje korištenje digitalnih online platformi u nastavi na daljinu te kombinacija s televizijskim lekcijama.

Cilj je rada dati kratki pregled suvremenih informacijskih i komunikacijskih alata, platformi i usluga korištenih u nastavi na daljinu te istražiti koji su od njih najčešće korišteni u nastavi stranih jezika na daljinu u osnovnoj školi. Za potrebe istraživanja samostalno je izrađen upitnik u Google Formsu za nastavnike stranih jezika (engleskoga, njemačkoga, talijanskoga) u osnovnim školama u Republici Hrvatskoj. Istraživanjem suvremenih informacijskih alata također je izrađen popis digitalnih alata i platformi kojima je svrha e-učenje i poučavanje te je svaki od njih opisan s obzirom na njegove temeljne značajke i funkcije i kritički mu se pristupa. Za svaki od njih dan je pregled prednosti i mogućih nedostataka u pogledu odgojno-obrazovnoga procesa te ostvarivanja nastavnih metoda u nastavi stranoga jezika pomoću navedenih informacijskih alata, kao i preporuka za unaprjeđenje nastave stranoga jezika. Bitno je naglasiti da su u istraživanju objedinjeni opći i specifični digitalni alati, odnosno oni koji služe poučavanju svih predmeta i onih koji služe poučavanju jezika.

\subsection{Teorijski okvir suvremenih informacijskih alata u obrazovanju}

Suvremene informacijske tehnologije i alati novijega su vijeka, pojavljuju se u 20. stoljeću pojavom računala. Prvo se pojavljuje pojam IT (informacijske tehnologije) koji podrazumijeva tehnologije koje koriste računala za prikupljanje, obradu, pohranu, zaštitu i prijenos podataka. Tu pripadaju računalne i telekomunikacijske tehnologije te tehnologije bazirane na optoelektronici i tehnologiji genetskoga inženjerstva (Pavičić, 2017).

Pojam IKT (Informacijsko-komunikacijske tehnologije) ili ICT (Information and Communication Technologies) pojavljuje se kasnije, širom uporabom elektroničke pošte. Sastoji se od više elemenata koji su u njegovu nazivu: informacije, komunikacija i (mrežna) tehnologija. Ovaj pojam označava ne samo svu tehnologiju za prikupljanje, obradu i pohranu informacija, već i prijenos i uporabu svih vrsta informacija. Pojam IKT u nastavi populariziran je tek 1997. godine kada ga je upotrijebio Dennis Stevenson kod promoviranja novoga nacionalnog kurikula u Velikoj Britaniji (Tamilselvan i sur., 2012).

U nastavi se razlikuju još sljedeći pojmovi vezani za informacijsko-komunikacijske tehnologije: DOS (digitalni obrazovni sadržaj) i SOT (suvremene obrazovne tehnologije), a označavaju sadržaje posredovane određenim tehničkim medijima i tehnologijama i obrazovnu tehnologiju. Obrazovna 
tehnologija podrazumijeva uporabu tehnologije za unaprjeđenje obrazovanja, odnosno e-učenje (e-learning). Prema Međunarodnoj udruzi za obrazovnu komunikaciju i tehnologiju obrazovna je tehnologija složen i integrirani pristup koji uključuje ljude, postupke, ideje, uređaje i organizaciju za analizu problema i osmišljavanje, provedbu, vrednovanje i upravljanje rješenjima, sudjeluje u svim područjima ljudskoga učenja. ${ }^{3}$ Cilj je poboljšanje nastave i procesa učenja (Ljubić Klemše, 2016). Tehnologija je prisutna kao suvremeni komunikacijski alat, ali i alat za prezentiranje, odnosno za postizanje ciljeva učenja i poučavanja i uspjeha u različitim aktivnostima učenja. Isprva se tehnologija u nastavi koristila za nadomjestak izvornoj stvarnosti ili kako bi se klasična nastava poboljšala, ali razvojem obrazovnih aplikacija, tehnologija je postala bitan čimbenik u učenju i poučavanju te stvaranju obrazovnih sadržaja, a ne samo njihovu prijenosu (Bognar, Matijević, 2005). Postoje i mješoviti oblici nastave, poput hibridne nastave u kojoj se nastava odvija dijelom u učionici, a dijelom pomoću tehnologija, tzv. virtualnih učionica.

Potreba za učenjem otvorenoga tipa (open-ended learning experience) u kojemu je pristup nastavnim sadržajima omogućen svim učenicima dovela je do sve većega stvaranja novih digitalnih obrazovnih sadržaja i novih suvremenih informacijskih alata. U primjeni je treća generacija e-učenja (e-learning 2.0) čiji je glavni element primjena 2.0 mrežnoga alata, a karakteristika postavljanje učenika u centar učenja i poučavanja uz pomoć ICT-a. Mrežni 2.0 alati su skupina programskih društvenih alata koji omogućavaju suradničko učenje, besplatni su i moguće ih je koristiti u nastavi (Ljubić Klemše, 2016.)

O važnosti IKT-a govori i UNESCO-ov dokument Information and Communication Technology in Education: A Curriculum for Schools and Programme of Teacher Development koji daje pregled faza kroz koje prolaze obrazovne institucije u procesu implementacije ICT-a u obrazovni sustav te razvoj učitelja koji su nositelji sustava. Navedene faze su: pojavljivanje (nabavljanje računalne opreme), upotreba (korištenje IKT-a u različitim područjima), integracija (uključivanje IKT-a u kurikul i učionice) i transformacija (IKT postaje nevidljiv dio nastavne prakse) (UNESCO, ICT Competency Framework for Teachers, 2018).

IKT omogućuje vremensku i prostornu neovisnost učenja i poučavanja, interaktivnost učenja, veću odgovornost za vlastito učenje, lakše integrira-

\footnotetext{
${ }^{3}$ https://narodne-novine.nn.hr/clanci/sluzbeni/2002_09_109_1753.html
} 
nje više predmeta čime se potiče međupredmetnost nastavnih tema i predmeta, itd. IKT također motivira učenike i osnažuje informacijsku pismenost kod učenika koja je jedan od ključnih elemenata suvremenoga obrazovanja. U primjeni IKT-a u nastavi velika je odgovornost na nastavnicima koji se u njihovoj uporabi trebaju voditi pedagoškim načelima kako bi poučavanje bilo primjereno i učinkovito (Bognar, Matijević, 2005).

U Nacionalnome okvirnome kurikulu Republike Hrvatske (2010) kao jedna od ključnih kompetencija ističe se digitalna kompetencija učenika koja se odnosi na osposobljenost za sigurnu i kritičku uporabu informacijsko-komunikacijske tehnologije u radu, u osobnom i društvenomu životu, i u komunikaciji (NOK, 2010: 19) Projekti kojima se osnažila digitalna pismenost i kompetencija u hrvatskim školama su CARNET-ovi projekti u suradnji s Agencijom za odgoj i obrazovanje, europskim fondovima i drugim suradnicima, a to su: „e-Škole: Uspostava sustava razvoja digitalno zrelih škola“ iz 2015. i „IKT Curricula“ iz 2013. koji su pružili nastavnicima i učenicima digitalnu potporu u obliku računalne podrške, priručnika i mrežnih seminara te su omogućile školama da postanu digitalno zrele. Uvođenje informatike kao obaveznoga predmeta u višim razredima osnovne škole te kao izbornoga predmeta u razrednoj nastavi ukazalo je na bitnu ulogu informacijsko-komunikacijskih tehnologija u obrazovanju. Potreba za poboljšanjem informacijske, digitalne i medijske pismenosti osobito se pokazala nužnom za vrijeme i nakon nastave na daljinu.

Dosadašnja istraživanja čitalačke pismenosti u nastavi pokazala su porast korištenja IKT-a u nastavi, poput međunarodnoga PISA istraživanja iz 2018. u kojemu se istražio stupanj digitalne pismenosti nastavnika i učenika u 79 zemlje, među kojima je i Hrvatska. Istraživanje je pokazalo veliki skok u dostupnosti računala i interneta u školi i kod kuće pa tako 67,4 \% učenika koristi školsko računalo spojeno na internet u školi, a čak 74,2 \% ima prijenosno računalo kod kuće, dok 94 \% ima internetsku vezu kod kuće. Prosječna dob prvog korištenja računala i interneta je od 7 do 9 godina. Istraživanjem je utvrđeno da učenici koji su s korištenjem digitalnih uređaja (tablet, prijenosno računalo) započeli ranije i koji manje vremena provedu na internetu u školi postižu bolji rezultat u učenju. Istraživanje je također pokazalo da je korištenje digitalnih uređaja u svrhu učenja i poučavanja najvidljivije na satima hrvatskoga i stranoga jezika (korištenje digitalnih uređaja: 21,5\% učenik i nastavnik, 9,3\% samo učenik, 27,6 \% samo nastavnik) (Dekanić i sur., 2019). Kada se radi o uporabi digitalnih uređaja u školi i kod kuće, učenici ih najviše koriste za dopisivanje na društvenim mrežama te pretraživanje interneta radi izvršavanja školskih obaveza. Gotovo više od 
polovice učenika nikad ili gotovo nikad ne koristi računalo za pisanje domaće zadaće (Dekanić i sur., 2019). Prijašnjim PISA istraživanjem iz 2012. također je utvrđeno da su razvijene zemlje poput Japana i Kine oprezne u uvođenju tehnologija u nastavu jer je istraživanjem također utvrđeno da učenici koji u velikoj mjeri koriste tehnologiju u nastavi postižu lošije rezultate u odnosu na one koji ih koriste umjereno. Zaključak najnovijega PISA istraživanja za digitalnu pismenost upućuje na to da bi sustavno trebalo razvijati informacijsko-komunikacijsku pismenost učenika u svim predmetima te da bi digitalne uređaje i internet trebalo koristiti svrhovito i u skladu sa strategijama poučavanja (Dekanić i sur., 2019.)

Istraživanje koje su proveli Pović i suradnici 2015. o korištenju IKT-a u nastavi, uključivalo je 1101 nastavnika u osnovnim i srednjim školama u Republici Hrvatskoj te je pokazalo da moderne tehnologije koristi 93,2 \% ispitanih nastavnika. Prosječan hrvatski nastavnik koji koristi tehnologije u nastavi ima između 30 i 40 godina te učenicima viših razreda osnovne škole ili srednjoškolcima predaje predmet iz područja društvenih ili prirodnih znanosti (Pović i sur., 2015). Rezultati ovoga istraživanja pokazali su veliku zainteresiranost nastavnika za korištenje IKT-a u nastavi. Ova su dva istraživanja izdvojena kao bitno polazište za istraživanje kojim se rad bavi, a uključuje dosadašnju primjenu IKT-a u nastavi stranih jezika u osnovnim školama u Republici Hrvatskoj.

\subsection{Vrste suvremenih informacijskih alata u obrazovanju}

Prema e-učenju suvremeni obrazovni mrežni alati mogu se podijeliti na više skupina prema njihovoj namjeni (Ljubić Klemše, 2016): alati za komunikaciju, prezentacijski alati, alati za suradnju, alati za razmjenu medija, alati za kreativno učenje, alati za izradu obrazovnih sadržaja, sustavi za upravljanje učenjem (LMS) i obrazovne igre. Bitno je naglasiti da podjela suvremenih informacijskih alata postoji onoliko koliko je i autora dotične literature, a u ovom radu dana je podjela koja zadovoljava pedagoške i obrazovne zahtjeve nastavnoga procesa. Pojedini se alati mogu svrstati i u više od jedne skupine jer imaju više namjena. U radu će se spominjati termini digitalna usluga, platforma i alat. Digitalna usluga širi je pojam i uključuje više programa i alata. Neki od primjera usluga korištenih u nastavi na daljinu su Office 365 i Google G Suite. Digitalna platforma podrazumijeva samostalnu i funkcionalnu mrežnu stranicu koja ima svoje alate, poput Zooma, Cisco Webexa i dr. Digitalni alat je najmanja digitalna jedinica koja uključuje specifične mogućnosti korištenja, poput alata za komunikaciju, npr. komunikacijski 
alat Yammer u okviru digitalne usluge Office 365. (e-skole.hr) U literaturi se još nalaze pojmovi program i aplikacija koji se često zamjenjuju pojmom alat i uglavnom se odnose na mobilne aplikacije koje nude ograničeno korištenje određene usluge.

Digitalni alati za komunikaciju služe za stvarnu i direktnu komunikaciju između dvoje i više ljudi koji koriste računalo i moguće ih je upotrijebiti za svaki oblik komunikacije (usmeni, pisani, vizualni). Takvi su alati za komunikaciju zastupljeni unutar digitalnih platformi Zoom, Skype, Cisco Webex, dok Googlova usluga G Suite nudi još komunikacijske alate Google Meet, Google Talk i Google Classroom. Microsoft 365 usluga nudi komunikacijski alat Yammer.

Prezentacijski alati služe za prezentiranje obrazovnih sadržaja na interaktivan i zanimljiv način, npr. Spark Adobe, Prezi, PowerPoint i drugi.

Alati za suradnju ili još suradnički alati služe za dijeljenje zajedničkih nastavnih materijala pri čemu svi korisnici mogu jednako uređivati nastavni materijal. Takvi su alati Padlet, Lino, RealTime Board i usluge poput Google diska i Dropboxa.

Alati za razmjenu medija omogućuju razmjenu fotografija, videa, prezentacija i ostalih digitalnih nastavnih sadržaja. To su Slideshare, LiveWorksheets, Padlet, Wizer i drugi.

Alati za kreativno učenje omogućuju zanimljiv i interaktivan pristup učenju i poučavanju poput Wordwalla, Learningappsa, Quizizza i drugih.

Alati za izradu obrazovnih sadržaja omogućuju nastavniku izradu nastavnih jedinica u digitalnome obliku, a učeniku izradu vlastitih prezentacija i domaćih uradaka. To su Spark Adobe, Learning Apps, Blendspace, Moovly i drugi.

Obrazovne igre omogućuju zanimljivo ponavljanje nastavnih sadržaja i obično služe za uvježbavanje nastavnih sadržaja. To su npr. Learning Apps, Wordwall, Quizizz i drugi.

Alati za izgradnju sustava za upravljanje učenjem (LMS) su alati koji se baziraju na Web 2.0. tehnologiji te čine sustav za provedbu obrazovnoga procesa, npr. Moodle, Loomen, Merlin, Canvas i drugi.

Neki od navedenih alata mogu se svrstati u više navedenih skupina zbog svojih postavki i obilježja. Značajno je spomenuti posebne obrazovne usluge poput Office 365 usluge i alata koji omogućuju suradnju i komunikaciju između svih sudionika u obrazovnom sustavu. Office 365 tako objedinjuje više suvremenih informacijskih alata na jednome mjestu poput Google Formsa, MS Teamsa, Worda, Excela, Powerpointa i slično. 


\subsubsection{Alati za komunikaciju}

Dva najpoznatija komunikacijska alata su Yammer u okviru usluge Office 365 i platforma Zoom. Yammer ${ }^{4}$ je preporučeni alat od strane CARNet-a za komunikaciju i suradnju unutar obrazovne ustanove u okviru usluge Office 365 za škole. To je društvena mreža koja omogućuje povezivanje i komunikaciju s velikim brojem osoba. U potpunosti je besplatna i dostupna učenicima i učiteljima u Republici Hrvatskoj. Ima jednostavno sučelje koje se sastoji od "zida objava“, pretinca s porukama i notifikacijama, i zato je pogodna za učenike. Omogućuje slanje svih vrsta datoteka te provođenje kratkih anketa među učenicima i učiteljima. Sličan alat je Google Classroom ${ }^{5}$. Nastavne metode koje se ovdje mogu ostvariti s obzirom na e-poučavanje su metoda razgovora i metoda pisanja. Prednost Yammera je što su pristup $\mathrm{i}$ korištenje za učenike i nastavnike jednostavni, a isto tako primjenjivost $\mathrm{u}$ nastavi je zadovoljavajuća jer omogućuje slanje svih vrsta datoteka učenicima te dvosmjernu komunikaciju. Nedostatak je što se preko Yammera ne može provjeriti učinkovitost učenja i poučavanja, što se jedino može napraviti pomoću anketnoga upitnika.

Zoom $^{6}$ je platforma za videokomunikaciju koji sadrži jednostavnu cloud platformu za video i audiosastanke, konferencije, treninge i mrežne seminare. Omogućava alate za dijeljenje dokumenata, fotografija, videa, dijeljenje ekrana sa sudionicima razgovora (screenshare), korištenje bijele ploče za komunikaciju i prezentiranje sudionicima (whiteboard), korištenje chata, snimanje komunikacije i dr. Zoom se može koristiti za virtualno izvođenje nastave. Besplatan je za korisnike, ali uz vremensko ograničenje od 40 minuta koje se ponovno može produžiti. Pomoću njega moguće je unaprijediti sve jezične vještine - slušanje, čitanje, pisanje, govorenje. Ima veliku učinkovitost u poučavanju jer više motivira učenike, omogućava višesmjernu komunikaciju među učenicima i učiteljem, brzina reakcije na učenički odgovor je trenutačna i druge prednosti. Nastavne metode koje se ovdje mogu ostvariti s obzirom na e-poučavanje su metoda razgovora, metoda usmenoga izlaganja, metoda čitanja i rada na tekstu i metoda pisanja. Platforme i alati sličnih značajki su Cisco Webex, Google Meet, MS Teams i Google Talk. Ovaj alat omogućuje primjenu gotovo svih nastavnih metoda i omogućuje direktnu povratnu informaciju učenicima, kao i evaluaciju naučenoga usmenim putem. Jedini je nedostatak pristup i jednostavnost kori-

\footnotetext{
${ }^{4}$ https://office365.skole.hr/default/login

${ }^{5} \mathrm{https} / / /$ classroom.google.com/u/0/h

${ }^{6}$ https://zoom.us/
} 
štenja alata jer je potrebna dodatna instalacija i uputa za korištenje alata za učenike. Ministarstvo znanosti i obrazovanja nije službeno odobrilo Zoom tako da većina nastavnika izbjegava ovakvu komunikaciju, no mogu se koristiti slični odobreni alati (Mješovita elektrotehnička i drvoprerađivačka srednja škola, 2019.)

\subsubsection{Prezentacijski alati}

Prezentacijski alati koji su opisani u nastavku su Spark Adobe i Loom. Spark Adobe $^{7}$ alat je za izradu prezentacija, postera, videa i drugih sličnih sadržaja. Registracija i korištenje su jednostavni i besplatni. U prezentacije mogu se umetati tekstualni i slikovni sadržaji, audio i videoisječci te mrežne stranice. Ima puno gotovih slikovnih predložaka i uradci se mogu dijeliti. U nastavi se većinom koristi za izradu zanimljivih postera i prezentacija te je namijenjena i učiteljima i učenicima. Zbog svoje efektne vizualne strane, zanimljivih slikovnih predložaka i fontova visoko je motivirajući alat te ima veliku učinkovitost u učenju i poučavanju. Nastavne metode koje se ovdje mogu ostvariti s obzirom na e-poučavanje su metoda čitanja i rad na tekstu. Prednost je visoka primjenjivost u nastavi jer omogućuje različite opcije predstavljanja nastavnoga sadržaja pomoću slike, zvuka, videa i slično. Nedostatak je što se preko ovoga alata ne može evaluirati niti mjeriti učinkovitost učenja i poučavanja, kao ni slati povratna informacija učenicima. Također, učenici ne mogu međusobno komunicirati preko ovoga alata, niti biti vidljivo aktivni.

Loom $^{8}$ je besplatni alat za snimanje ekrana računala. Snimke koje se izrade u Loomu skladište se u Loomovo cloud skladište. Loom uključuje jednostavan alat za rezanje početka i kraja snimka, pri snimanju omogućava pauziranje snimaka u bilo kojemu trenutku i nastavak snimanja naknadno. Može snimati ekran i mrežnu kameru, ili samo zaslon, ili samo mrežnu kameru. Snimka se pohranjuje na loom.com, ali može se preuzeti u MP4 formatu. Što se tiče primjene u nastavi, odličan je za snimanje videolekcija za poučavanje, čime omogućava veću učinkovitost u učenju učenika jer nudi zorno, slušno, vizualno primanje informacija na daljinu. Nastavne metode koje se ovdje mogu ostvariti s obzirom na e-poučavanje su metoda usmenoga izlaganja i metoda čitanja i rada na tekstu. Jedini je nedostatak što se preko Looma ne može mjeriti učinkovitost učenja i poučavanja niti slati povratna informacija (Marketing Fancier Blog, 2019.)

\footnotetext{
${ }^{7} \mathrm{https} / / / \mathrm{www}$. adobe.com/express/

${ }^{8}$ https://www.loom.com/
} 


\subsubsection{Alati za suradnju}

U pregledu alata za suradnju dan je opis dvaju najpopularnijih, a to su Padlet i usluga Google disk. Padlet ${ }^{9}$ je mrežni alat namijenjen suradnji. Koristi se kao "prazan papir”, tj. online zid na kojemu se mogu dodavati ideje, recenzije, obavijesti, informacije, učitavati slike i dokumente, a mogu se i drugim sudionicima omogućiti sve navedeno. Odlikuje ga jednostavnost korištenja, dostupnost na različitim uređajima, prilagođenost potrebama korisnika i raznovrsna namjena. Omogućuje pregledno učenje i poučavanje, a ponajviše objavu već gotovih rezultata učenja, poput školskoga panoa. Nudi izvrstan pregled učeničkih postignuća. Slični su alati Lino i RealTime Board, sa sličnim postavkama. Nastavne metode koje se ovdje mogu ostvariti s obzirom na e-poučavanje su metoda razgovora i metoda pisanja. Ovaj je alat visoko primjenjiv u nastavi, omogućuje dvosmjernu komunikaciju te povratne informacije, kao i online evaluaciju.

Google Disk ${ }^{10}$ besplatna je Googlova usluga. Omogućava jednostavno stvaranje novih dokumenata na mreži, dodavanje postojećih dokumenata, organizaciju u datoteke, dijeljenje dokumenata i istovremeni rad više korisnika na jednom dokumentu u stvarnom vremenu. Osim toga, mogu se izraditi proračunske tablice, prezentacije, obrasci za ankete, crteži i drugo (Edutorij.e-skole.hr). Prednost je što su dokumenti dostupni u bilo koje vrijeme i s bilo kojeg računala spojenoga na internet. Koristan je za primjenu u nastavi jer omogućava komunikaciju, suradnju i istovremenu suradnju grupe korisnika na istom projektu. Učitelju omogućuje direktan uvid u rezultate učenja i poučavanja učenika te direktnu komunikaciju s njima radi povratne informacije. Od nastavnih metoda ovim se alatom može najviše ostvariti metoda pisanja.

\subsubsection{Alati za razmjenu medija}

U pregledu alata za razmjenu medija dani su opisi Slidesharea, Liveworksheetsa i Wizera. Slideshare ${ }^{11}$ je mrežni alat koji služi za dijeljenje prezentacija i dokumenata. Sve što je potrebno za korištenje Slidesharea je internetska veza i mrežni preglednik. Za pregledavanje uradaka ostalih korisnika ne treba se registrirati, a usluga je besplatna. Neke od mogućnosti Slidesharea su slanje i spremanje prezentacije, povezivanje s drugim mrežnim pro-

\footnotetext{
${ }^{9}$ https://padlet.com/dashboard

${ }^{10} \mathrm{https}$ ///www.google.hr/drive/about.html

${ }^{11}$ https://www.slideshare.net/
} 
gramima, kao i mogućnost ostavljanja komentara i povratnih informacija o uratku (Pogled kroz prozor, 2010.) U nastavi može poslužiti za dijeljenje nastavnih sadržaja učenicima i davanje povratnih informacija, no njime se ne može sa sigurnošću mjeriti učinkovitost učenja i poučavanja. Nastavne metode koje se ovdje mogu ostvariti s obzirom na e-poučavanje su metoda razgovora i metoda pisanja.

LiveWorksheets ${ }^{12}$ i Wizer ${ }^{13}$ su mrežni alati koji se koriste za stvaranje interaktivnih nastavnih listića i njihovo dijeljenje. Ovi su alati posebno važni za vrednovanje naučenoga. Uglavnom su besplatni i jednostavni za korištenje. Zadaci u listiću mogu biti različitoga tipa: zadaci dopunjavanja, povezivanja, višestrukoga izbora, zadaci otvorenoga tipa, zadaci za poticanje diskusije, zadaci koji omogućuju snimanje odgovora u obliku audio i videozapisa te zadaci koji omogućuju crtanje i označavanje slika. Učitelj može snimiti pitanje u obliku audio ili videozapisa što ovaj alat čini pogodnim za prilagodbu učenja.

Učitelj kreira razredne odjele kojima se učenici pridružuju nakon što se registriraju. U besplatnoj inačici moguće je stvoriti najviše dva razreda. Radni listići mogu se podijeliti s učenicima unutar razreda te putem e-maila ili lozinke. Učitelj može pratiti predane radove, a rezultati učenika prikupljaju se u izvještaju koji se može preuzeti na računalo. Moguće je podesiti da je povratna informacija automatska, npr. u zadacima višestrukoga izbora, povezivanje, dok u zadacima otvorenoga tipa učitelj piše ili snima povratnu informaciju. Nastavne metode koje se ovdje mogu ostvariti s obzirom na e-poučavanje su metoda razgovora i metoda pisanja. Visoka je primjenjivost navedenih alata u nastavi zbog njihove interaktivnosti, dvosmjerne komunikacije, mogućnosti evaluacije i jednostavnoga pristupa.

\subsubsection{Alati za kreativno učenje}

U okviru alata za kreativno učenje i obrazovne igre dani su opisi Wordwalla i Learningapppsa. Wordwall ${ }^{14}$ je alat za stvaranje obrazovnih kvizova, uparivanja, igre riječi i drugih obrazovnih igara. Alat je jednostavan i u određenoj mjeri besplatan za korištenje te je moguće koristiti već gotove igre za dijeljenje. Iznimno je primjenjiv u svim nastavnim predmetima i omogućuje učeniku samostalno praćenje svojega napretka i dodatno interaktivno uvježbavanje nastavnoga sadržaja. Omogućuje trenutačnu povrat-

\footnotetext{
${ }^{12}$ https://www.liveworksheets.com/

${ }^{13}$ https://www.wizer.me/

${ }^{14}$ https://wordwall.net/
} 
nu informaciju o napretku. Alat je izuzetno primjenjiv i primjeren u nastavi te omogućuje povratne informacije i evaluaciju naučenoga.

LearningApps ${ }^{15}$ je mrežno sjedište gdje korisnici mogu pronaći različite besplatne alate ili pomoću predložaka izraditi vlastite za primjenu u nastavi. Alati su napravljeni i osmišljeni kao maleni interaktivni moduli koji se mogu uključiti u nastavne materijale, ali i primijeniti za samostalno učenje (Valčić, 2017.) Za korištenje postojećih alata nije potrebna prijava ili registracija i korisnik ih može primijeniti u nastavi bez ograničenja. Learning Apps nastavnicima omogućava izradu različitih alata kao dodatak svojoj nastavi i zadataka za samostalno učenje. Dostupnost raznolikih predložaka omogućava prilagodbu različitim situacijama i sadržajima koje nastavnici predaju, a izrada razreda omogućava jednu zatvorenu zajednicu gdje nastavnik ima uvid u to koliko dobro učenici rješavaju zadane zadatke i ima li netko od učenika problema s usvajanjem nastavnoga sadržaja. Izrada je alata jednostavna, ali nedostatak je što određena sučelja nisu u potpunosti prevedena na engleski, već je tekst na njemačkom izvornom jeziku. Ovaj je alat visoko primjenjiv u nastavi, omogućuje povratnu informaciju o naučenome te svojim interaktivnim sučeljem motivira učenike na rad.

\subsubsection{Alati za izgradnju sustava za upravljanje učenjem (LMS - Learning Management System)}

Alati za izgradnju sustava za upravljanje učenjem počeli su se razvijati još 1996. godine, a objedinjuju sve potrebne alate za izradu i dostavljanje sadržaja za učenje, kvizove i testove, komunikaciju, bilježenje podataka o učenicima itd. Primjeri LMS sustava su Moodle, Loomen, WebCT, Claroline, Sakai, A Tutor i drugi (Hoić-Božić i sur., 2008.)

Moodle $^{16}$ je alat za izradu elektroničkih obrazovnih sadržaja i održavanje nastave na daljinu. To je modularan sustav što znači da se sastoji od manjih cjelina koje korisnici po potrebi mogu dodavati i mijenjati. Alat omogućava izradu novih sadržaja uz pomoć različitih resursa ili integriranje gotovih, unaprijed pripremljenih elektroničkih sadržaja. Alat omogućava i planiranje nastave, upravljanje korisnicima, provjeru znanja i ocjenjivanje, praćenje aktivnosti te komunikaciju (Nacionalni portal za učenje na daljinu „Nikola Tesla", 2017.)

\footnotetext{
${ }^{15}$ https://learningapps.org/

16 https://moodle.com/
} 


\section{METODOLOGIJA ISTRAŽIVANJA}

\subsection{Cilj istraživanja i hipoteze}

Istraživanje suvremenih informacijskih alata u nastavi stranih jezika u osnovnim školama potaknuto je planiranjem i provođenjem nastave na daljinu u društvenim i obrazovnim okolnostima koje su opisane u uvodu ovoga rada i željom za njezinim unaprjeđenjem. Kao što je u prethodnim poglavljima rečeno, informacijsko-komunikacijska tehnologija već je niz godina predmet vrijedan istraživanja, a osobito kada se radi o nastavnome procesu koji je dinamičan i mijenja se iz dana u dan. Cilj je istraživanja kojim se rad bavi istražiti koji su suvremeni informacijski alati najčešće korišteni u nastavi stranih jezika za vrijeme nastave na daljinu od sredine ožujka do sredine lipnja 2020. godine u osnovnim školama u Republici Hrvatskoj; u kojem stupnju su jezične vještine ostvarene pomoću suvremenih informacijskih alata prema ispitanicima; kakav je stav nastavnika stranih jezika kada je riječ o ostvarenosti odgojno-obrazovnih ishoda u nastavi stranoga jezika te koje su prednosti i nedostaci suvremenih informacijskih alata koje su koristili u nastavi na daljinu. Omogućiti pisanu i usmenu komunikaciju u nastavi stranoga jezika predstavljao je velik izazov za nastavnike stranoga jezika u nastavi na daljinu, osobito kada je riječ o usmenoj komunikaciji i govorenju, ne samo nastavnika, već i učenika. Hipoteze istraživanja izvedene su analizom pojedinih alata u prethodnim odjeljcima i iskustvom iz vlastite prakse.

Hipoteze istraživanja su:

H1: posredovanje nastavnoga sadržaja suvremenim informacijskim alatima ne omogućava podjednak razvoj svih jezičnih vještina

H2: odgojno-obrazovni ishodi u nastavi stranih jezika nisu mogli biti u potpunosti ostvareni primjenom suvremenih informacijskih alata u nastavi na daljini

H3: nastavnici stranih jezika pozitivno su usmjereni na korištenje IKT-a u nastavi stranoga jezika.

\subsubsection{Uzorak i metodologija istraživanja}

Istraživanjem je obuhvaćen uzorak od 58 nastavnika stranih jezika (engleskoga, njemačkoga, talijanskoga i francuskoga). Od toga je 56 nastavnica, a 2 su nastavnika stranoga jezika. Svi predaju u osnovnoj školi u Republici Hrvatskoj. 40 je nastavnika/ica engleskoga, 13 je nastavnika/ica njemačkoga, 4 je nastavnika/ica talijanskoga, a 1 je nastavnik/ica francuskoga. 40 je nastavnika/ica engleskoga jezika, a od toga njih 25 predaje engleski kao prvi 
strani jezik, 10 predaje engleski kao drugi strani jezik, a 5 predaje engleski kao izvannastavnu aktivnost. 13 je nastavnika/ica njemačkoga jezika, a od njih 3 predaje njemački kao prvi strani jezik, 8 predaje njemački kao drugi strani jezik, a 2 predaje njemački kao izvannastavnu aktivnost. 4 je nastavnika/ica talijanskoga jezika, a 1 francuskoga.

U istraživanju je korištena kvantitativna metoda istraživanja. Istraživanje je provedeno u srpnju 2020, a kao instrument istraživanja korišten je anketni upitnik izrađen u Google obrascu. Upitnik se sastoji od 14 pitanja zatvorenoga, otvorenoga i kombiniranoga tipa, a pitanja su vezana za suvremene informacijske alate u nastavi stranoga jezika. Upitnik je anoniman i podijeljen je na društvenim mrežama nastavnika stranih jezika (Facebook grupe Jezičari, Engleski jezik u OŠ, Njemački jezik u OŠ, Talijanski jezik u $O S \check{S}$ ) te članovima HUPE-a (Hrvatskog udruženja profesora engleskog jezika), a dostupan je na sljedećoj poveznici: https://docs.google.com/forms/d/e/. Rezultati upitnika predstavljeni su deskriptivnom analizom podataka u kojima se brojčano i grafički opisuju dobiveni statistički podaci, a vezani su za pitanja zatvorenoga i kombiniranoga tipa. Rezultati pitanja otvorenoga tipa predstavljena su kvalitativno i opisuju stavove nastavnika stranih jezika kada je riječ o prednostima i nedostacima korištenja suvremenih informacijskih i komunikacijskih alata $u$ nastavi te njihovoj preferenciji u korištenju navedenih alata.

\subsubsection{Rezultati istraživanja}

Prvo će se analizirati rezultati pitanja zatvorenoga i kombiniranoga tipa. Sljedeća pitanja tiču se konkretne primjene suvremenih informacijskih alata u nastavi stranih jezika te njihov prikaz slijedi u nastavku.

Tijekom nastave na daljinu koristio/la sam sljedeće suvremene informacijske usluge, alate i komunikacijske kanale: e-pošta, Yammer, Zoom, Spark Adobe, Loom, Prezi, Padlet, Google disk, Dropbox, Slideshare, Liveworksheets, Wizer, Wordwall, Class Dojo, WhatsApp, Viber, Teams, Kahoot, Google Forms, Google Classroom, ostalo. Navedeno pitanje bilo je višestrukoga izbora tako da su nastavnici mogli izabrati više alata koje su koristili u nastavi, ali i dodati svoj odgovor (kombinirani tip pitanja) (Slika 1.) Prema odgovorima ispitanika, najčešće korišteni suvremeni informacijski alat u nastavi stranih jezika na daljinu je Wordwall (87,9 \%) koji spada u alate za kreativno učenje. Slijede e-pošta (77,6 \%) kao najčešći komunikacijski kanal, Liveworksheets (60,3 \%), Zoom (53,4 \%), Teams (51,7 \%), Viber $(51,7$ \%), Kahoot (48,3 \%), Google disk (48,3\%), Wizer (46,6 \%), Padlet (41,4\%), Loom (41,4 \%), Yammer (41,4\%), Google Classroom (39,7\%), Google 
Forms (39,7 \%), Spark Adobe (37,9\%), WhatsApp (32,8\%), Dropbox (12,10 $\%)$, Class Dojo (10,3 \%), Slideshare (8,6 \%), Prezi $(3,4 \%)$ te ostalo $(1,7 \%)$ (Slika 1.) Alati za komunikaciju (Zoom, Teams), alati za kreativno učenje (Wordwall, Kahoot) i alati za razmjenu medija (Liveworksheets) najviše su korišteni u nastavi stranih jezika na daljinu, zatim slijede alati za suradnju (Padlet, Google disk) te prezentacijski alati (Loom, SparkAdobe). Nastavnici su navodili još neke alate i komunikacijske kanale koje su koristili, ali ti su alati zastupljeni u manjem postotku: Bookwidgets, Edmod, Quizlet, Educaplay, Vocaroo, Quizizz, Messenger, Learningapps, Linoit, Genially, Word i Powepoint.

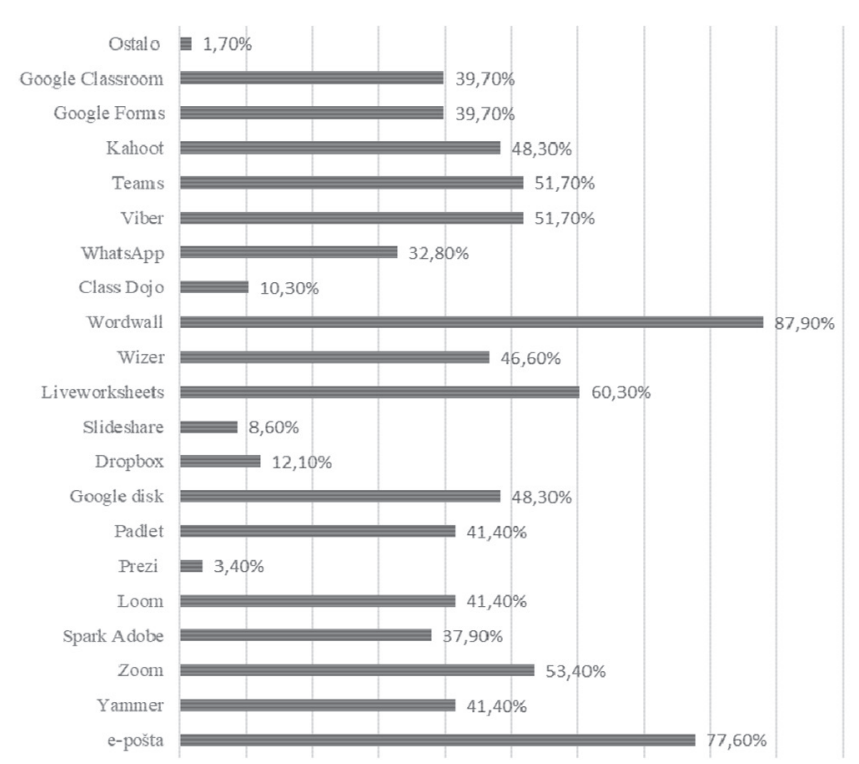

$0,00 \% \quad 10,00 \% 20,00 \% 30,00 \% \quad 40,00 \% 50,00 \% \quad 60,00 \% \quad 70,00 \% \quad 80,00 \% \quad 90,00 \% 100,00 \%$

Slika 1. Postotak učestalosti korištenja pojedinoga suvremenog informacijskog alata u nastavi stranoga jezika u osnovnoj školi

Sljedeće pitanje odnosilo se primjenu pojedinoga suvremenog informacijskog alata u ostvarenju određenoga odgojno-obrazovnoga ishoda. $\mathrm{U}$ pitanju su dani primjeri ishoda svih triju domena predmetnoga kurikula za engleski jezik u osnovnoj školi: komunikacijska jezična kompetencija (4 ishoda), međukulturna komunikacijska kompetencija (2 ishoda) i samostalnost u ovladavanju jezikom (1 ishod) (Kurikulum nastavnog predmeta Engleski jezik za osnovne škole i gimnazije, 2019). Ponuđeni usluge i alati su: Yammer, Zoom, SparkAdobe, Loom, Padlet, Wordwall, WhatsApp, Kahoot, e-pošta, PowerPoint, Microsoft Word ili nešto drugo (zatvoreno pi- 
tanje). Pitanje glasi: Koji biste suvremeni informacijski alat / komunikacijski kanal koristili u ostvarenju sljedećih odgojno-obrazovnih ishoda?

Nastavnici za ostvarenje ishoda Prepoznaje grafijke slike jednostavnih riječi $(O \check{S}(1) E J A 1.2$.) najčešće navode alate za kreativno učenje poput Wordwalla $(68,9 \%)$ i Kahoota $(20,7 \%)$ te prezentacijske alate poput PowerPointa $(27,6$ \%) i SparkAdobea (22,4\%) Slabije su zastupljeni alati i usluge Microsoft Word (10,3 \%), Yammer (8,6 \%), Zoom (8,6 \%), Padlet (6,9\%), Loom (5,2 \%), WhatsApp (1,7 \%), e-pošta (1,7\%) i nešto drugo (8,6\%) (Slika 2.$)$

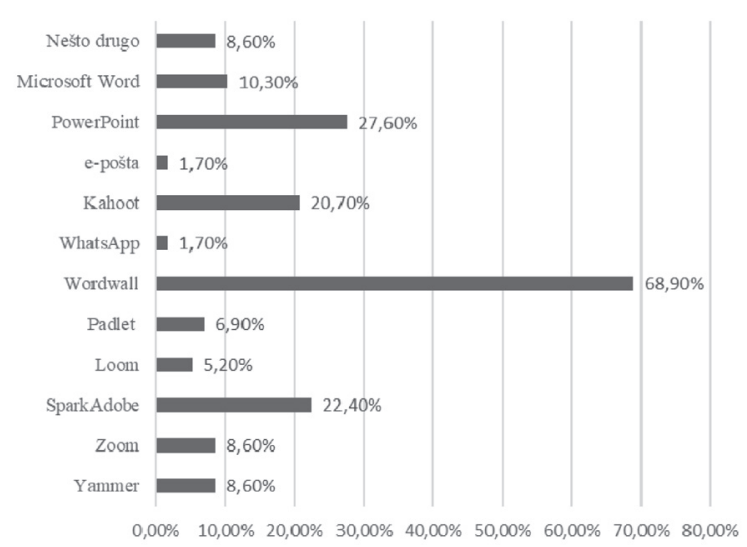

Slika 2. Korištenje suvremenih informacijskih alata u ostvarenju OŠ (1) EJ A1.2. ishoda

Nastavnici za ostvarenje ishoda Razumije kratak tekst poznate tematike pri slušanju i čitanju (OŠ(1) EJ A5.1.) najčešće navode komunikacijski alat Zoom (22,4 \%) i prezentacijske alate Loom (22,4\%) i PowerPoint (20,7 \%). Zanimljivo je da nastavnici ipak u ostvarenju navedenoga ishoda pribjegavaju drugim alatima, čak njih 32,7\% (Slika 3.)

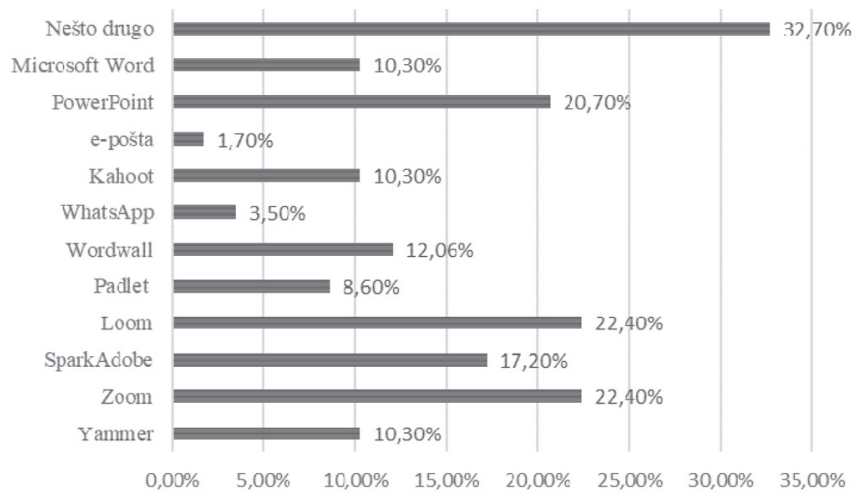

Slika 3. Korištenje suvremenih informacijskih alata u ostvarenju OŠ (1) EJ A5.1. ishoda 
Nastavnici za ostvarenje ishoda Govori vrlo kratak $i$ jednostavan tekst (OŠ(1) EJ A4.5.) najčešće navode komunikacijske alate i platforme poput Zooma (55,2 \%) i WhatsAppa (27,6 \%). Slabije su zastupljeni alati Loom $(10,3 \%)$, Padlet (8,6 \%), Kahoot (1,7 \%), e-pošta (6,9\%), PowerPoint (5,2 \%), Microsoft Word (1,7\%), dok se neki uopće ne koriste u ostvarenju navedenoga ishoda (Wordwall, SparkAdobe, Yammer). Velik dio nastavnika ipak pribjegava korištenju drugih suvremenih informacijskih i komunikacijskih alata $(36,2 \%)$ (Slika 4.)

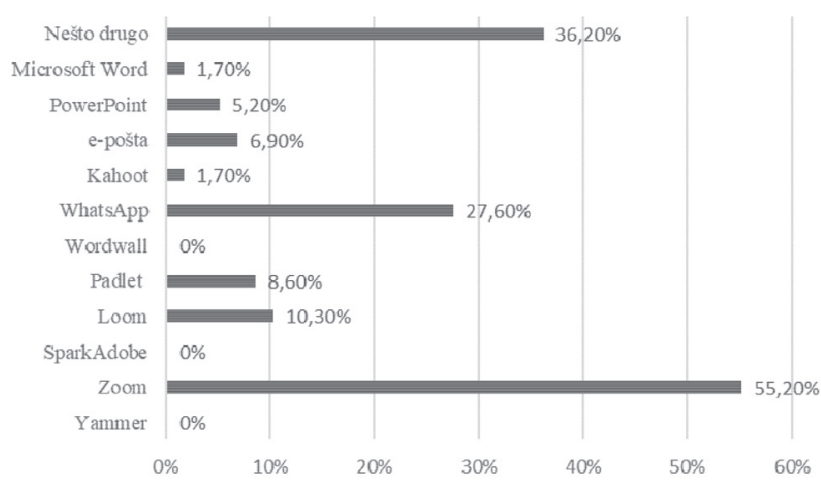

Slika 4. Korištenje suvremenih informacijskih alata u ostvarenju OŠ (1) EJ A4.5. ishoda

Nastavnici za ostvarenje ishoda Piše kratak strukturiran tekst poznate tematike koristeći se jednostavnim jezičnim strukturama i primjenjuje osnovna pravopisna pravila (OŠ(1) EJ A6.6.) najčešće navode alate iz Office 365 usluge: Microsoft Word (60,3 \%), PowerPoint (24,1 \%) i Yammer (18,9 \%). E-poštu kao bitan komunikacijski kanal u ostvarenju navedenoga ishoda navodi čak $31 \%$ ispitanika te alate za suradnju (Padlet) 17,2\%. Ostali su alati manje zastupljeni: SparkAdobe (5,2 \%), Wordwall (5,2 \%), Kahoot (3,5 $\%)$, Loom (17, \%), nešto drugo (18,9\%). Zoom uopće ne koriste za ostvarenje ovoga ishoda (Slika 5.) 


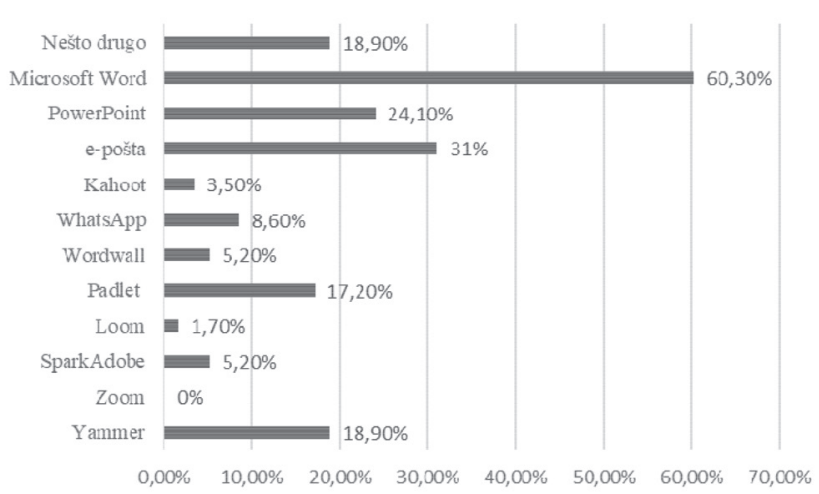

Slika 5. Korištenje suvremenih informacijskih alata u ostvarenju OŠ (1) EJ A6.6. ishoda

Za ostvarenje ishoda Održava kratku i jednostavnu komunikaciju koristeći se ključnim konvencijama uljudnoga ponašanja u međukulturnim susretima (OŠ(1) EJ B5.2.) nastavnici najčešće koriste komunikacijske alate i platforme poput Zooma (51,7 \%), Yammera (20,7 \%), WhatsAppa (15,5 $\%)$, e-pošte $(10,3 \%)$ i druge $(18,9 \%)$. To su ujedno i neki od najčešćih oblika komunikacije tijekom nastave na daljinu između nastavnika i učenika. Ostale alate za ostvarivanje ovoga ishoda koriste $\mathrm{u}$ jako malom postotku jer oni imaju neku drugu svrhu, npr. prezentacijski alati: SparkAdobe $(5,2$ $\%)$, Loom (5,2 \%), PowerPoint (6,9\%); zatim alati Padlet (3,4 \%), Microsoft Word (3,4 \%), alati za kreativno učenje Wordwall $(1,7 \%)$ i Kahoot $(3,4 \%)$ (Slika 6.)

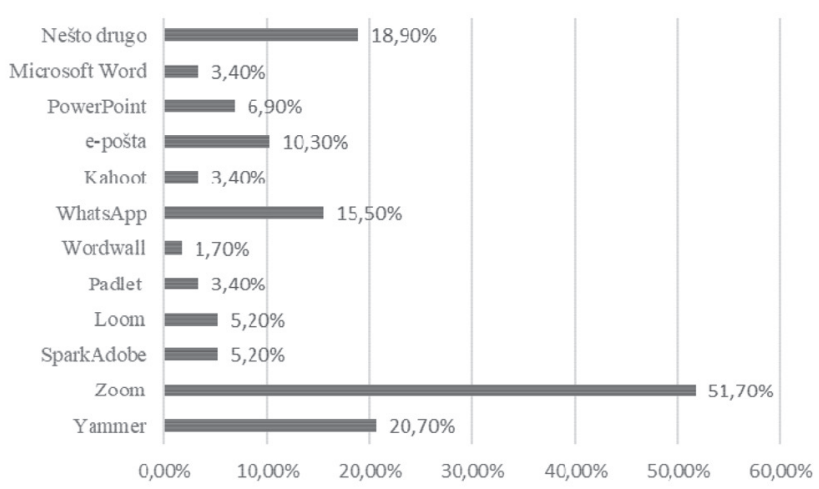

Slika 6. Korištenje suvremenih informacijskih alata u ostvarenju OŠ (1) EJ B5.2. ishoda

Nastavnici za ostvarenje ishoda Primjenjuje osnovna znanja o zemljama ciljanoga ciljnoga jezika unutar vlastite kulture (OŠ(1) EJ B5.1.) najviše kori- 
ste kombinaciju prezentacijskih (PowerPoint - $31 \%$, Spark Adobe - 13,8 \%) i komunikacijskih alata (Zoom - 25,9\%, Yammer - 18,9\%) te alate za suradnju (Padlet - 15,5\%). Često koriste i neke druge alate (25,9\%). U manjoj mjeri koriste ostale navedene alate: Microsoft Word (13,8 \%), Kahoot (12,1 \%), e-pošta (12,1 \%), Loom (6,9 \%), Wordwall (6,9\%) i WhatsApp (5,2 \%) (Slika 7.)

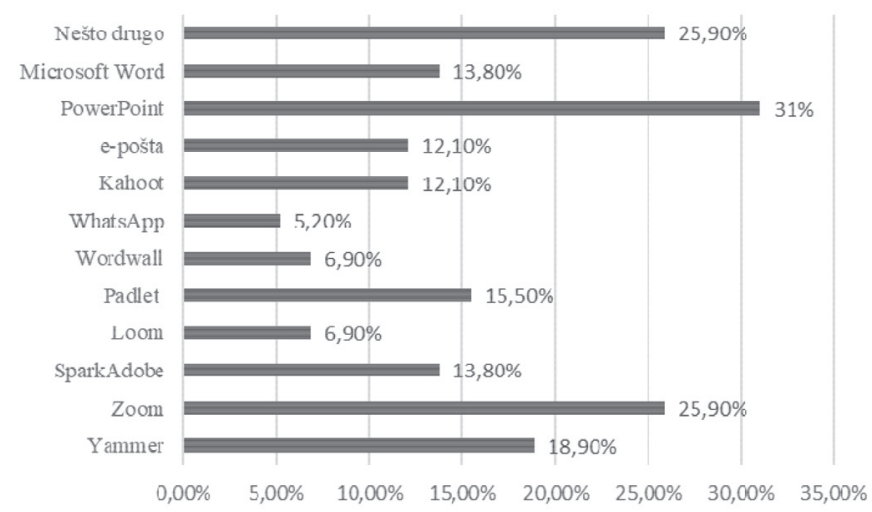

Slika 7. Korištenje suvremenih informacijskih alata u ostvarenju OŠ (1) EJ B5.1. ishoda

Nastavnici za ostvarenje ishoda Prilagođava najosnovnije kognitivne strategije učenja jezika različitim zadacima (OŠ(1) EJ C4.1.) najčešće navode alate za kreativno učenje (Wordwall - 20,7 \%, Kahoot - 15,5\%), alate za komunikaciju (Zoom - 17,2 \%, Yammer - 15,5\%) te prezentacijske alate (SparkAdobe - 15,5\%), ali najčešće nalaze druge alate kojima ostvaruju ovaj ishod, čak njih $39,6 \%$. Ostali su alati zastupljeni u manjem postotku: PowerPoint (13,8 \%), Padlet (8,6 \%), WhatsApp (5,2\%), e-pošta (5,2 \%), Loom (3,4\%) te Microsoft Word (3,4\%) (Slika 8.)

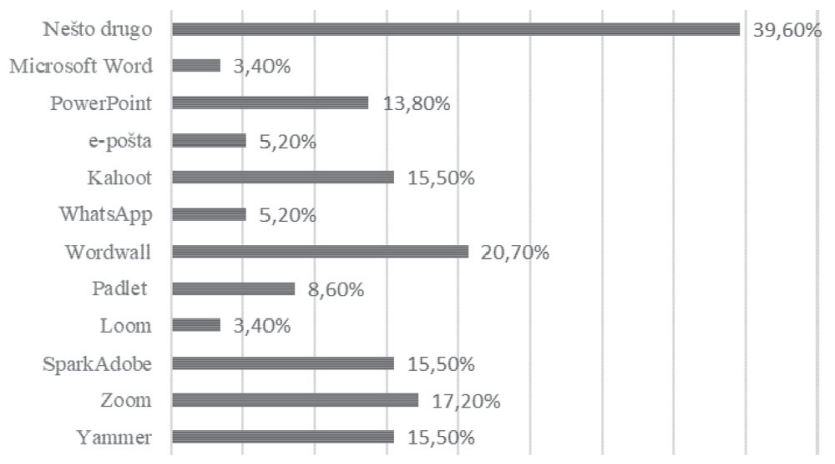

$0,00 \% \quad 5,00 \% 10,00 \% 15,00 \% 20,00 \% 25,00 \% 30,00 \% 35,00 \% 40,00 \% 45,00 \%$ 
Sljedeće pitanje zatvorenoga tipa odnosilo se korištenje suvremenih informacijskih alata prije same nastave na daljinu: Koliko ste često prije nastave na daljinu koristili suvremene informacijske alate u nastavi? 51,7 \% ispitanika odgovorilo je da ih je koristilo ponekad, 41,4 \% često, a 6,9\% nikad (Slika 9.)

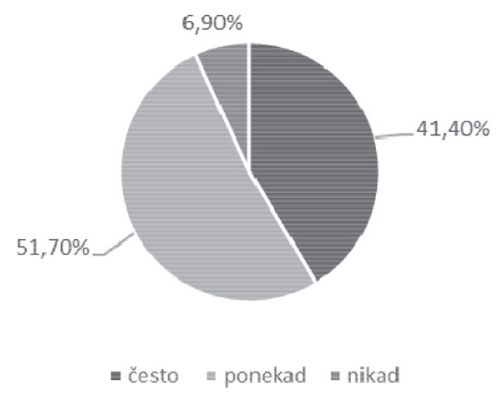

Slika 9. Učestalost uporabe suvremenih informacijskih alata prije nastave na daljinu

Pitanje o ostvarenosti ishoda tijekom nastave na daljinu također je bilo zatvorenoga tipa i glasilo je: Prema Vašemu mišljenju, $u$ kojoj su mjeri ostvareni odgojno-obrazovni ishodi tijekom nastave na daljinu? Velik postotak $(56,9 \%)$ ispitanika smatra da su ishodi djelomično ostvareni, $29,3 \%$ smatra da su većinom ostvareni, 6,9\% smatra da ih većinom nije bilo moguće ostvariti, $3 \%$ smatra da ishodi nisu ostvareni, a isto toliko 3,4 \% smatra da su ishodi u potpunosti ostvareni (Slika 10.)

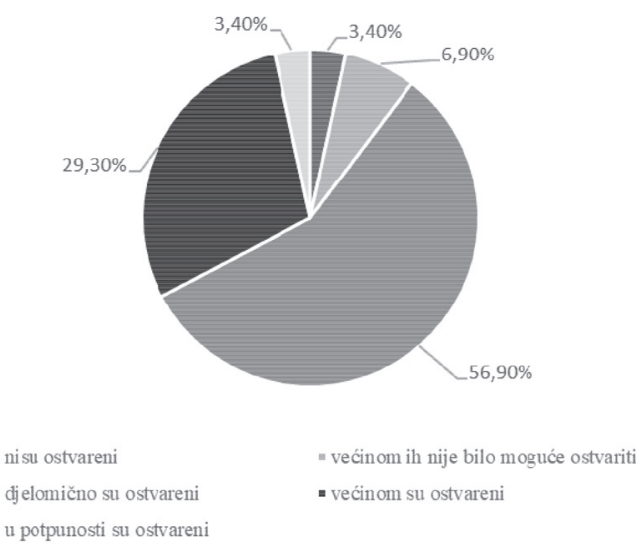

Slika 10. Ostvarenost ishoda učenja za vrijeme nastave na daljinu prema mišljenju nastavnika/ica

Ispitanike se također pitalo u kojoj je mjeri prema njihovome mišljenju moguće razvijati jezične vještine slušanja, govorenja, čitanja i pisanja u 
okviru nastave na daljinu: Prema Vašemu mišljenju, u kojoj je mjeri moguće razvijati sljedeće jezične vještine tijekom nastave na daljinu: slušanje, čitanje, govorenje i pisanje. Rezultati pokazuju da kada je riječ o vještini slušanja $31 \%$ ispitanika smatra da je tu vještinu moguće u potpunosti ostvariti, odnosno razvijati; 34,5 \% smatra da je slušanje uglavnom moguće ostvariti; $22,4 \%$ smatra da ju je djelomično moguće ostvariti; $12 \%$ smatra da većinom nije moguće ostvariti vještinu slušanja, a nitko ne smatra da ju je u potpunosti nemoguće ostvariti.

$34,5 \%$ ispitanika smatra da je u potpunosti moguće ostvariti vještinu čitanja tijekom nastave na daljinu, 32,8 \% smatra da ju je uglavnom moguće ostvariti, 20,7 \% smatra da ju je djelomično moguće ostvariti, 10,3 \% smatra da ju većinom nije moguće ostvariti, a 1,7 \% smatra da ju je u potpunosti nemoguće ostvariti.

6,9 \% ispitanika smatra da se vještina govorenja može u potpunosti ostvariti i razvijati tijekom nastave na daljinu, 27,6 \% smatra da ju je uglavnom moguće ostvariti, 39,6 \% smatra da ju je djelomično moguće ostvariti, 25,9 $\%$ smatra da ju većinom nije moguće ostvariti, a nitko ne misli da ju je u potpunosti nemoguće ostvariti.

$25,9 \%$ ispitanika smatra da je u potpunosti moguće ostvariti i razvijati vještinu pisanja tijekom nastave na daljinu, $43 \%$ smatra da je to uglavnom moguće, 25,9 \% smatra da je djelomično moguće ostvariti, 3,4 \% smatra da većinom nije moguće ostvariti, a samo $1,7 \%$ smatra da u potpunosti nije moguće razvijati vještinu pisanja tijekom nastave na daljinu (Slika 11.)

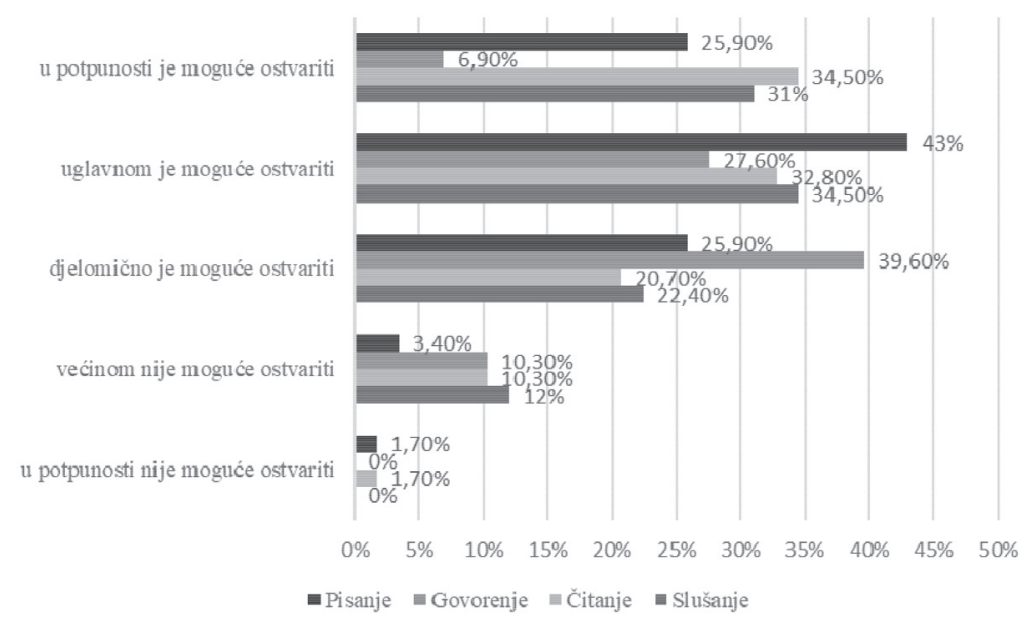

Slika 11. Ostvarenost jezičnih vještina tijekom nastave na daljinu prema mišljenju nastavnika/ica 
Sljedeća dva pitanja kombiniranoga tipa odnosila su se na suvremene informacijske alate koje su ispitanici koristili za predstavljanje nastavnoga sadržaja učenicima te evaluaciju istih. Na pitanje višestrukoga izbora Nove sam nastavne sadržaje uglavnom predstavljao/predstavljala učenicima: prezentacijom (PPT ili drugo), audio objašnjenjima (zvučni zapisi), nastavom uživo putem Zooma ili drugoga alata, samostalno snimljenih video lekcija (pomoću Looma ili drugoga alata), upućivanjem na druge izvore (Škola $z a$ život $i$ slično) te ostalo ispitanici su u velikom postotku odgovorili da koriste neku vrstu prezentacijskoga alata (36,2 \%), zatim samostalno snimljene videolekcije pomoću alata za prezentaciju ili razmjenu medija $(34,5 \%)$, dok je manji postotak korištenja audioobjašnjenja (6,9 \%), nastave uživo $(6,9 \%)$, upućivanjem na druge izvore $(5,2 \%)$ i ostalo (10,3\%). Pod ostalo ispitanici navode: Wizer.me, svoje nastavne jedinice prema planu i programu, videolekcije s interneta i drugih kolega, kombinaciju (postavljanje Assignment u Teamse koji su ponekad sadržavali prezentaciju, ponekad poveznice na neke alate, a ponekad i nastavu uživo putem JitsiMeeta), pisane upute i povremene videolekcije (Slika 12.)

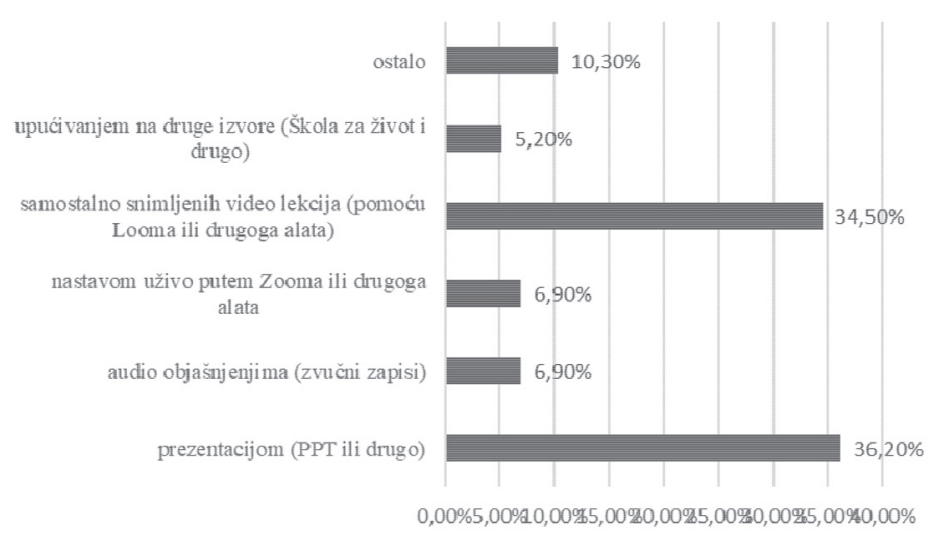

Slika 12. Suvremeni informacijski alati u predstavljanju nastavnoga sadržaja u nastavi na daljinu

Na pitanje višestrukoga izbora $\mathrm{Na}$ koje ste načine provjeravali ostvarenost odgojno-obrazovnih ishoda: pisanom provjerom u nekome od suvremenih alata (uz zadani vremenski okvir), kvizom, usmeno putem Zooma ili sličnoga alata, učenici bi poslali uslikani riješeni zadatak $i$ ostalo? Ispitanici su u najvećem postotku odgovorili da su usvojenost nastavnoga sadržaja u nastavi stranih jezika na daljinu provjeravali i evaluirali slanjem uslikanoga riješenog zadatka $(77,6 \%)$, zatim kvizom $(51,7 \%)$ te pisanom provjerom u nekome od suvremenih alata $(44,8 \%)$, dok je manji postotak odgovorio da je 
evaluirao sadržaj usmenim putem u nekome od suvremenih alata (15,5\%) i nekim drugim oblicima online provjeravanja (19\%). Pod ostalo ispitanici su naveli: složeni zadatak, online zadaci u Assignmentu (Teams), zvučne i videosnimke (projektni zadaci), učenici bi snimili čitanje i poslali audio ili videoporuku na Viberu, kreativnim zadatkom izrade stripa ili plakata, provjerom riješenoga listića s registracijom na platformama Wizer, Wordwall Learningapps, projektni zadatak, sami bi poslali videozapis u kojem govore nešto i projektni zadatak - Loom.

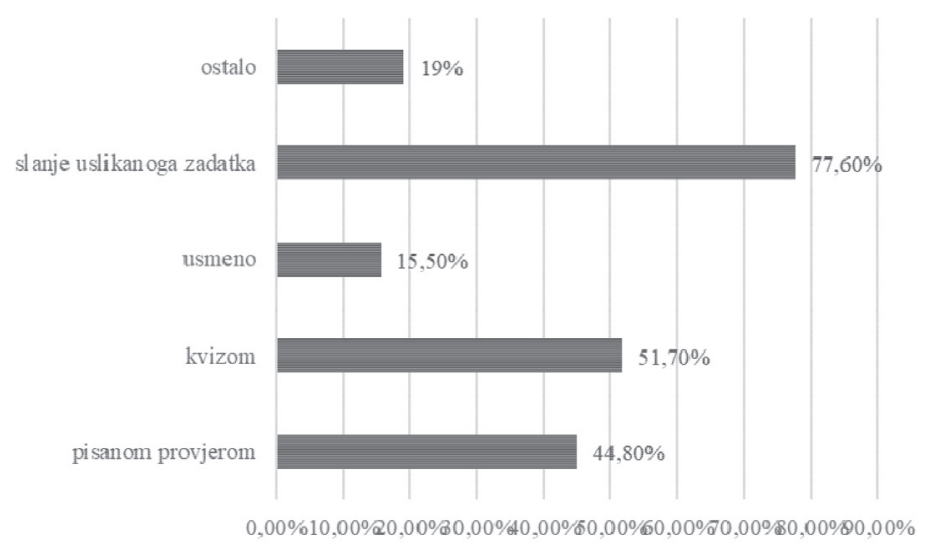

Slika 13. Suvremeni informacijski alati u evaluaciji nastavnoga sadržaja u nastavi na daljinu

Sljedeće je pitanje zatvorenoga tipa: Je li Vas nastava na daljinu potaknula da i u nastavi u školi (uživo) ubuduće češće koristite suvremene informacijske alate? $\mathrm{Da} / \mathrm{Ne}$. 77,6 \% ispitanika je potvrdno odgovorilo, dok je $22,4 \%$ odgovorilo negativno.

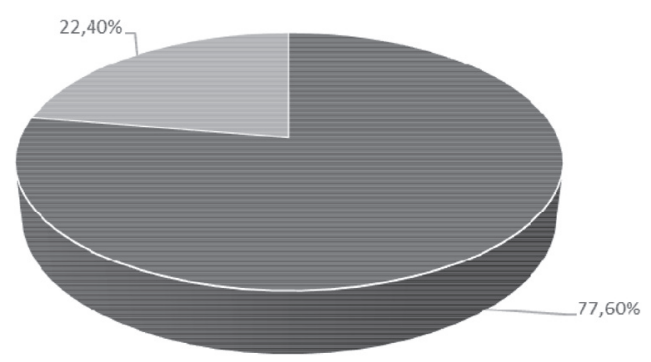

- da $=$ ne

Slika 14. Utjecaj nastave na daljinu na buduće korištenje suvremenih informacijskih alata 
Sljedeća su pitanja otvorenoga tipa u kojima se od ispitanika tražio njihov osobni stav prema nastavi na daljinu i suvremenim informacijskim alatima. Budući da ispitanici predaju i nižim i višim razredima osnovne škole, bilo je potrebno istražiti i razliku u vrsti suvremenih informacijskih alata koji su korišteni u nastavi na daljinu s mlađim i starijim učenicima. Pitanjem Ovisno o dobi učenika, koje ste suvremene informacijske alate koristili u nastavi za učenike mlađe školske dobi (7. - 10. g.), a koje za starije učenike (11. - 14. g.)? nastojalo se odgovoriti na postavljeni problem. U Tablici 1. prikazani su suvremeni informacijski alati korišteni u nastavi na daljinu za mlađe i starije učenike (Tablica 1 ).

Tablica 1. Suvremeni informacijski alati korišteni u nastavi na daljinu za mlađe i starije učenike u osnovnoj školi

\begin{tabular}{|l|l|}
\hline $\begin{array}{l}\text { Suvremeni informacijski alati i } \\
\text { mlađi učenici }\end{array}$ & Suvremeni informacijski alati i stariji učenici \\
\hline Kahoot & Learning Apps, Liveworksheets, Kahoot \\
Googdwall & Google Forms, Wordwall \\
Wizer.me & Spark Adobe, Book Creator \\
Google Slides & Wizer. me \\
Viber & Teams: PowerPoint, grafički alati (izrada postera i umnih mapa) \\
Quizizz & Canva \\
Google Sites & Quizizz \\
WhatsApp & Yammer \\
Class Dojo & Genially, edpuzzle \\
Izzi & Google Classroom \\
Youtube & Bookwidget \\
Loom & Edmodo, e-mail \\
Dropbox & Zoom, Loom \\
Weebly & Izzi, Youtube \\
Quizlet & Padlet \\
Blog & Microsoft Forms \\
Edmodo & Facebook \\
PowerPoint & Quizlet \\
online zadaci izdavača & Jitsi Meet, Vocaroo \\
\hline
\end{tabular}


Sljedeća dva pitanja otvorenoga tipa odnosila su se na prednosti i nedostatke suvremenih informacijskih alata tijekom nastave na daljinu, pa je u nastavku dan pregled odgovora ispitanika. Pitanja glase: Koje ste prednosti korištenja suvremenih informacijskih alata zamijetili tijekom nastave na daljinu? te Koje ste nedostatke korištenja suvremenih informacijskih alata zamijetili tijekom nastave na daljinu, odnosno s kojim ste se problemima suočavali?

Tablica 2. Prednosti i nedostaci korištenja suvremenih informacijskih alata tijekom nastave na daljinu

\begin{tabular}{|c|c|}
\hline Prednosti & Nedostaci \\
\hline 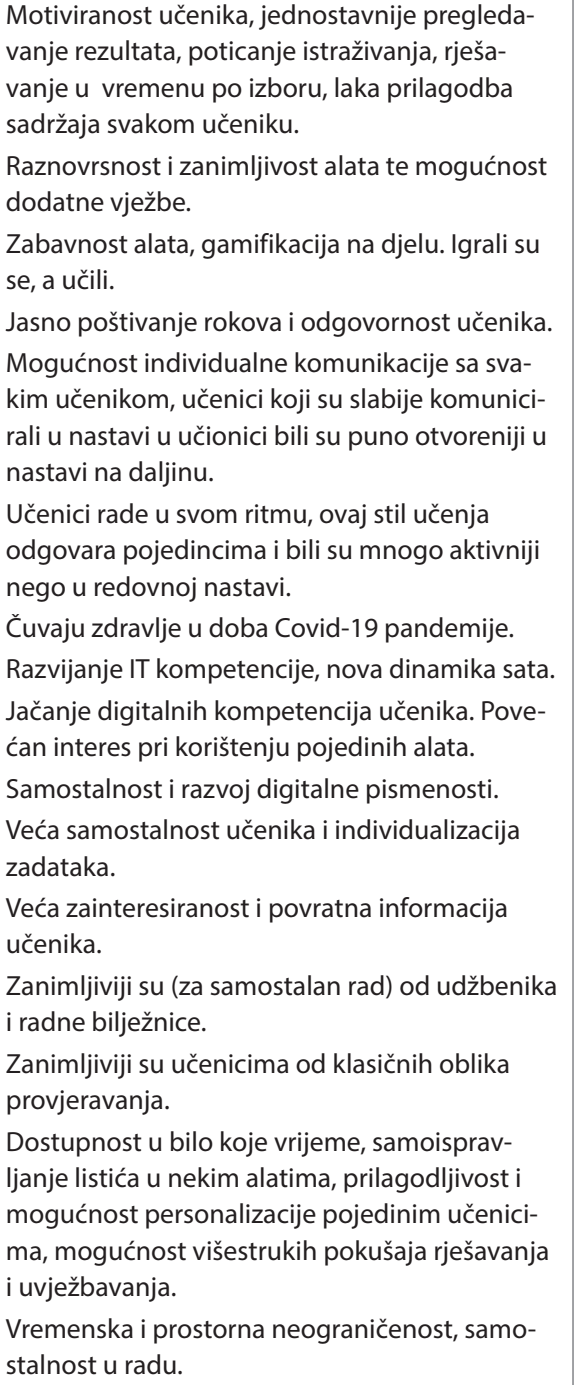 & $\begin{array}{l}\text { Tehničke poteškoće. } \\
\text { Teže je vidjeti reakciju učenika na govor i upute. } \\
\text { Nema objektivne povratne informacije, odgođe- } \\
\text { na povratna informacija. } \\
\text { Informatička (ne)pismenost pojedinih učenika, } \\
\text { loša internetska veza. } \\
\text { Ništa ne može zamijeniti nastavu uživo. } \\
\text { Nemogućnost provjere autentičnosti učeničkih } \\
\text { radova. } \\
\text { Manjak samostalnosti u radu kod nekih učenika, } \\
\text { prepisivanje. } \\
\text { Poteškoće u prezentiranju gramatičkih struktura. } \\
\text { Motivacija, kontakt. } \\
\text { Gubi se humanizam. } \\
\text { Nemaju sva djeca uvjete za takav rad kod kuće, } \\
\text { nedostatak nadzora rezultira zadaćama koje nisu } \\
\text { napisali sami učenici. } \\
\text { Nesudjelovanje svih učenika, nemogućnost } \\
\text { trenutne povratne informacije. } \\
\text { Ispravljanje automatskih odgovora (zbog razma- } \\
\text { ka, točke ili zareza im odgovori ne bi bili priznati } \\
\text { kao točni). Nedostatak ljudskog kontakta. } \\
\text { Vremenski jako zahtjevno (dok su se pronašli } \\
\text { odgovarajući alati - trebalo je sve pregledati i } \\
\text { istražiti, a onda ih je trebalo dobro proučiti kako } \\
\text { funkcioniraju), učitelji su služili kao tehnička } \\
\text { podrška učenicima i roditeljima, nevjerodostoj- } \\
\text { nost rezultata, tj. nemogućnost utvrđivanja jesu li } \\
\text { učenici (sami) odrađivali zadatke. } \\
\text { Slaba informatička pismenost roditelja/učenika. } \\
\text { Učenici nisu ostvarili sve ishode, niti smo uspjeli } \\
\text { provjeriti stečena znanja. }\end{array}$ \\
\hline
\end{tabular}




\begin{tabular}{|c|c|}
\hline Prednosti & Nedostaci \\
\hline $\begin{array}{l}\text { Nema fizičkog prenošenja nastavnih sredstava } \\
\text { po učionicama. } \\
\text { Brže povratne informacije o razumijevanju ili } \\
\text { nerazumijevanju obrađenoga. } \\
\text { Prva prednost je što nema printanja } \\
\text { beskonačnih papira, druga, djeci je klikanje po } \\
\text { monitoru prirodno kao hodanje, tako da je sve } \\
\text { teklo glatko. } \\
\text { Nema potrebe za stalnim objašnjavanjima jer je } \\
\text { sve napisano i objašnjeno. Izostanak disciplin- } \\
\text { skih problema. } \\
\text { Jednostavnost uporabe, moguće lakše prikupiti } \\
\text { povratnu informaciju u jednom alatu, fleksibil- } \\
\text { nost. } \\
\text { Roditelji provjere prije konačnog slanja zadatka. }\end{array}$ & $\begin{array}{l}\text { Neozbiljnost pojedinih roditelja i učenika, previše } \\
\text { uplitanja roditelja u rješavanje zadataka. Nerealni } \\
\text { rezultati pojedinih učenika. } \\
\text { Izostajanje klasične suradnje učenik- učitelj, } \\
\text { nedovoljno razvijene informatičke kompetencije } \\
\text { učenika i roditelja, slaba internetska veza, sporost } \\
\text { učitavanja sadržaja, cjelodnevno sjedenje za lap- } \\
\text { topom, cjelodnevno nošenje mobitela uza sebe, } \\
\text { burn out sindrom i kod učitelja i učenika, gubitak } \\
\text { topline osobnog komuniciranja u živo. } \\
\text { Nepostojanje vise računala/tableta u obitelji za } \\
\text { redovito pristupanje nastavi, zamorno za oči. } \\
\text { Nemogućnost vježbanja govora. } \\
\text { Pripreme su vremenski previše zahtjevne. } \\
\text { Nepridržavanje zadanih rokova za slanje zada- } \\
\text { taka. } \\
\text { Nisu objektivni. } \\
\text { Zasićenje kod učenika jer je sve online, većina } \\
\text { učenika nema koncentraciju za samostalni rad pa } \\
\text { samo prelete lekciju, preskaču zadatke, naprave } \\
\text { samo dio. } \\
\text { Poteškoće u čitanju s razumijevanjem, neke } \\
\text { učenike je bilo teško motivirati za aktivno i redo- } \\
\text { vito sudjelovanje. } \\
\text { Stalna dostupnost učitelja. } \\
\text { Nedostatak motivacije i natjecateljskog duha - } \\
\text { zbog izolacije od vršnjaka. } \\
\text { Problem u organizaciji vremena za rad, valjano i } \\
\text { pouzdano vrednovanje. } \\
\text { Nastava na daljinu kod stranog jezika ne funk- } \\
\text { cionira - zbog izgovora i jezičnih igara. } \\
\text { Ovisnost mlađih učenika o roditeljima. }\end{array}$ \\
\hline
\end{tabular}

Kao najčešće prednosti navode se individualnost pri poučavanju, unaprjeđenje digitalne pismenosti i fleksibilnost alata, dok se kao najčešći nedostaci navode poteškoće u prezentiranju pojedinih nastavnih sadržaja, nesudjelovanje pojedinih učenika i tehničke poteškoće.

Na pitanje Koji biste suvremeni informacijski alat izdvojili kao najkorisniji u nastavi stranoga jezika? ispitanici su odgovorili da su im sljedeći alati najkorisniji: Wordwall, Wizer, Liveworksheets, Loom, Zoom i alati za snimanje videa poput Obs studia. Ispitanici su u manjem broju naveli i ove alate i usluge: Spark Adobe, MS Teams, Bookwidget, digitalni udžbenici, Genially, Kahoot, LearningApps, Google Meet, Edmodo, Padlet, Quizizz, Vocaroo, PowerPoint, Yammer, Facebook, Freecam. Neki ispitanici navode 
da nema najkorisnijega alata, već da je bitna sinergija različitih pristupa i alata ovisno o željenom ishodu te da alate treba koristiti umjereno.

Zadnje pitanje otvorenoga tipa odnosilo se na moguće prijedloge u vezi $\mathrm{s}$ unaprjeđenjem suvremenih informacijskih alata u nastavi: Imate li prijedlog kako bi se određeni suvremeni informacijski alati mogli unaprijediti kako bi poučavanje bilo još učinkovitije? Neki od prijedloga su sljedeći:

Razvijati hrvatske IKT alate za poučavanje jezika primjerene našem jeziku i potrebama HR školstva, olakšati pristup učenicima, a istovremeno zaštititi njihov identitet, omogućiti besplatno korištenje alata učiteljima, kvalitetno $i$ moderno poučavati digitalne kompetencije od 1.r. Oঙ̌.

Nemam. Alati su poprilično dobri. Ono što treba poboljšati su uvjeti za rad djeci jer neka sela i kućanstva mojih učenika ili nemaju potrebnu tehniku ili je nema dovoljno za svako dijete u obitelji (tamo gdje ima više školaraca $u$ obitelji).

Uz dobru internetsku vezu kod svih učenika većina alata može se koristiti tokom nastavne godine kao podrška pa makar i u vidu dodatnih zadataka, lista procjena, kratkih provjera, samoprocjene...

Umjerenim korištenjem tehnologija treba biti samo produžena ruka čovje$k a$, bez pretjerivanja... čovjek treba ovladavati tehnologijom, humanizirati ju, a ne podleći tehnokraciji...

Koristiti ih češće kako bi učenici zaista usvojili način upotrebe bez pomoći starijih. Mogućnost korištenja pojedinih alata bez prethodne registracije korisnika.

Omogućiti školama nabavu licenci za alate koja je onemogućena zbog komplikacija oko $R 1$ računa, predračuna, e-računa, naručivanja preko riznice... Kod ispravljanja odgovora na kvizu, ne penalizirati razmak, zarez, malo slovo kao grešku, tj. omogućiti vise varijacija točnih odgovora.

Ima ih ionako previše. Nije li liječnička preporuka za očuvanje zdravlja psihe i očiju maksimalno dva sata dnevno gledanja u ekrane?

Mislim da učinkovitost poučavanja ni na koji način ne ovisi o upotrebi informacijskih alata pa tako niti o njihovom unapredivanju.

Nemam prijedlog, jer mislim da ih je već sada previše, a da nam njihove mogućnosti nisu dobro prezentirane.

Vremenska ograničenja rada $i$ ulaska u format, varijacije pitanja $i$ odgovora, autom. povratna informacija...

U sve bi trebalo uvesti mogućnost snimanja glasa i ograničavanje vremena rješavanja.

Samo osigurati tehničku podršku da svi alati i aplikacije neometano funkcioniraju. 
Omogućiti više opcija, odnosno oblika pitanja te više alata za provjeru slušanja.

Mogućnost video komunikacije u stvarnom vremenu unutar platforme poput Wizera.

Automatskim slanjem obavijesti o aktivnosti pošto učenici zaborave na zadatke.

Dati više samostalnosti učenicima u kreiranju uradaka.

Wordwall za provjeranje naučenog na zabavan način.

Učiniti ih besplatnima.

Edukacijom nastavnika.

Kao najčešće prijedloge za unaprjeđenje alata nastavnici navode osiguravanje tehničke podrške i nadograđivanje dodatnih mogućnosti pojedinih alata, edukaciju učenika, nastavnika i roditelja o mogućnostima alata te omogućavanje besplatnih licenci za pojedine alate.

\subsubsection{Rasprava}

Provedeno istraživanje ukazuje na činjenicu da ispitanici koji su sudjelovali u ovom istraživanju najčešće koriste alate kojima se može osnažiti više jezičnih vještina istovremeno te koji motiviraju učenike na aktivno bavljenje jezikom. Najčešće biraju alate za kreativno učenje poput Wordwalla i Liveworksheetsa te platforme i alate za komunikaciju poput Zooma i Teamsa. Kada se radi o specifičnim jezičnim vještinama, za ostvarenje vještine slušanja i govorenja najčešće koriste komunikacijske alate koji omogućavaju metodu razgovora Zoom ili WhatsApp, dok za vještinu čitanja najčešće koriste prezentacijske alate Loom, PowerPoint, ali i platformu Zoom. Za ostvarenje vještine pisanja najčešće koriste alate iz paketa Office 365 poput Microsoft Worda i PowerPointa koji omogućuju digitalno uređivanje teksta. Navedeni rezultati ukazuju na korištenje suvremenih informacijskih alata u skladu s njihovom namjenom i mogućnostima koje pružaju. Ispitanici ne navode univerzalan alat koji bi bio jedinstven sve jezične vještine, ali najbliže tome su komunikacijski alati koji omogućavaju razgovor s učenicima i potiču ponajprije govorne i slušalačke vještine. Rezultati pokazuju da ispitanici vide alate za izradu edukativnih sadržaja i obrazovne igre (Wordwall, Kahoot, Wizer i drugi) korisnima za razvoj kognitivnih strategija učenja i međukulturno učenje. Kada je riječ o ostvarenosti ishoda, stav je većine nastavnika da su oni djelomično ostvareni. Razlog tome može se naći u ograničenim mogućnostima pojedinih alata, ali i drugim nedostacima nastave na daljinu koje nastavnici navode: niska motiviranost učeni- 
ka, manjak samostalnosti kod nekih učenika i nepridržavanje vremenskih rokova. Također treba uzeti u obzir da su u istraživanju dobiveni odgovori koji su možda pod utjecajem nedovoljne metodičke osposobljenosti korištenja platformi, usluga, aplikacija i alata. Nastavnici koji su sudjelovali $\mathrm{u}$ istraživanju također vide veliku prednost u korištenju suvremenih informacijskih alata u nastavi stranih jezika: individualizirani pristup nastavi i svakom pojedinom učeniku, poticanje istraživačkoga učenja, razvijanje digitalne pismenosti, eko-održiva nastava bez nepotrebnoga tiskanja i drugi.

Prva hipoteza istraživanja koja kaže da posredovanje nastavnoga sadržaja suvremenim informacijskim alatima ne omogućava podjednak razvoj svih jezičnih vještina je potvrđena što se može vidjeti iz rezultata. Ispitanici smatraju da se vještine slušanja $(65,5 \%)$, čitanja $(67,3 \%)$ i pisanja $(68,9 \%)$ u većoj mjeri mogu u potpunosti ili uglavnom mogu ostvariti i razvijati pomoću suvremenih informacijskih alata, što ne smatraju i za vještinu govorenja (34,5\%). Razlog tome može se pripisati ograničenim mogućnostima i izborom alata u svrhu unaprjeđenja govornih vještina, ali i provjere istih. Druga hipoteza je također potvrđena; odgojno-obrazovni ishodi u nastavi stranih jezika nisu mogli biti u potpunosti ostvareni primjenom suvremenih informacijskih alata u nastavi na daljini. Čak 56,9 \% ispitanika smatra da su ishodi djelomično ostvareni, a samo 32,7 \% smatra da su ishodi u potpunosti ili većinom ostvareni. Razlozi tomu mogu se također pronaći u ograničenim mogućnostima pojedinih alata, nedostatku motivacije kod učenika i nepoznavanje svih mogućnosti pojedinih alata. Treća je hipoteza također potvrđena; nastavnici stranih jezika pozitivno su usmjereni na korištenje IKT-a u nastavi stranoga jezika. Govore to i podaci da je čak 41,4 \% ispitanika prije nastave na daljinu često koristilo IKT u učionici te 77,6 \% ispitanika nastavilo bi ih koristiti i nakon nastave na daljinu, što je znatan porast u broju prije i poslije nastave na daljinu. Ovaj rezultat sličan je i rezultatu istraživanja Pović i sur. (2015.) u kojemu moderne tehnologije koristi 93,2 \% ispitanih nastavnika u osnovnim i srednjim školama, poglavito u društvenim znanostima.

Unatoč tome što nastavnici u pitanjima otvorenoga tipa navode više nedostataka nego prednosti suvremenih informacijskih alata, $u$ prijedlozima za njihovo poboljšanje navode konstruktivne komentare koji upućuju na pozitivan stav prema njihovu korištenju i želji za njihovim unaprjeđenjem. Navode da je u korištenju suvremenih informacijskih alata potreban umjeren pristup i ravnoteža u korištenju različitih alata te da je iznimno važno više humanizirati tehnologiju, osobito kada je riječ o jeziku i specifičnim 
jezičnim vještinama. U tome pravcu bilo bi ih poželjno nadograđivati i usmjeravati.

\section{ZAKLJUČAK}

U izvanrednim situacijama poput globalne pandemije virusa suvremeni informacijski alati su postali potreba, a ne izbor. Novonastalom situacijom suvremeni informacijski alati itekako su zakoračili u odgojno-obrazovni sustav, a na odgojno-obrazovnim djelatnicima je da ih na pametan, odgovoran i smislen način integriraju u učenje i poučavanje. Suvremeni informacijski alati mogu se prema svojoj namjeni podijeliti u nekoliko kategorija: alati za komunikaciju, prezentacijski alati, alati za suradnju, za razmjenu medija, za kreativno učenje, za izradu obrazovnih sadržaja, obrazovne igre, alati za izgradnju sustava za upravljanje učenjem i drugi. Postoje i druge kategorije, ali u istraživanju su obuhvaćene one najreprezentativnije u odgojno-obrazovnome procesu te njihove karakteristike. Unatoč svim prednostima, još uvijek e-učenje ne može zamijeniti u potpunosti klasičan pristup učenju, ali zato može pružiti kreativniji i složeniji pristup učenju i poučavanju te unaprijediti odgojno-obrazovni proces, ako se koristi uravnoteženo s ostalim nastavnim sredstvima. Nijedan alat ne može u potpunosti zamijeniti rad na satu i predavanje u školi, odnosno ljudsku komunikaciju, osobito kada se radi o stranome jeziku. Komunikacija uživo uvijek ima u sebi element životnosti, empatije i intuitivnosti, dok računalo ne može u potpunosti prenijeti isto. U nastavi jezika osobito je važna komunikacija uživo zbog čistoće i jasnoće izgovora. Prema upitniku može se zaključiti da nastavnici stranih jezika pribjegavaju alatima kojima se može osnažiti više jezičnih vještina istovremeno te koji motiviraju učenike na aktivno bavljenje jezikom.

Zahvaljujem svojoj mentorici na poslijediplomskome doktorskom studiju Humanističke znanosti Sveučilišta u Zadru, prof. dr. sc. Marijani Kresić Vukosav, na svim sugestijama $i$ komentarima na ovaj rad.

\section{LITERATURA}

Betts, K., Gomez, K., Mawhinney, T. Welcome to Generation Z. https://www2.deloitte. $\mathrm{com} /$ content/dam/Deloitte/us/Documents/consumer-business/welcome-to-gen-z.pdf (pristupljeno 10. 6. 2020.)

Bognar, L., Matijević, M. (2005) Didaktika. Zagreb: Školska knjiga.

Burns, Mary (2020) We Are All Distance Learners: Online Education Across The Globe-Part 2. E-learning industry: https://elearningindustry.com/distance-learners-online-educationacross-the-globe-part-2 (pristupljeno: 16. siječnja 2020.) 
Činko, Mateja (2016) Upotreba informacijske i komunikacijske tehnologije u nastavi. Rijeka: Filozofski fakultet.

E-laboratorij: http://e-laboratorij.carnet.hr/ (pristupljeno 20. 5. 2020.)

E-škole: Rješenja za provedbu nastave na daljinu: https://www.e-skole.hr/rjesenja-zaprovedbu-nastave-na-daljinu/ (pristupljeno 20. 4. 2021.)

Edutorij (2019) Edutorij.e-skole.hr (pristupljeno: 20. 5. 2020.)

Hoić-Božić, Nataša, Mornar, Vedran, Botički, Ivica. (2008) Introducing adaptivity and collaborative support into a Web-based LMS. U: Computing and Informatics. Zagreb: Fakultet elektrotehnike i računarstva.

Ljubić Klemše, N. Novi pristupi učenju i poučavanju uz informacijsko-komunikacijsku tehnologiju: https://www.slideshare.net/natasaljubicklemse/novi-pristupi-uenju-i-pouavanju-uzpodrku-ikta (pristupljeno 20.5. 2020.)

Marketing Finacier Blog (2019) Najbolji besplatni programi za snimanje ekrana računara https://marketingfancier.com/najbolji-besplatni-programi-za-snimanje-ekrana-racunara/

Markočić Dekanić, Ana, Gregurović, Margareta, Batur, Matija, Fulgosi, Sanja. (2019.) PISA 2018: Rezultati, odrednice i implikacije: Međunarodno istraživanje znanja $i$ vještina učenika. Zagreb: Nacionalni centar za vanjsko vrednovanje obrazovanja.

Ministarstvo znanosti i obrazovanja. (2019) Kurikulum nastavnoga predmeta Engleski jezik za osnovne škole i gimnazije. Zagreb: Narodne novine.

Mješovita elektrotehnička i drvoprerađivačka srednja škola (2019) Aplikacija Zoom. Uputstvo za učenike. Bihać.

Pavičić, Jelena (2017) Informacijsko-komunikacijska tehnologija u nastavi. Zagreb: Filozofski fakultet.

Pogled kroz prozor, digitalni časopis za obrazovne stručnjake (2010) https://pogledkrozprozor. wordpress.com/2010/09/29/koristenje-mreznog-servisa-slideshare-za-objavljivanjedokumenata/ (pristupljeno: 20.5. 2020.)

Pović, Tea, Veleglavac, Katarina, Čarapina, Mia, Jagušt, Tomislav, Botički, Ivica. (2015) Primjena informacijsko-komunikacijske tehnologije u osnovnim $i$ srednjim školama $u$ Republici Hrvatskoj. U: Proceedings of the Carnet User Conference. Zagreb: Carnet.

Škola za život - digitalni alati: https://skolazazivot.hr/adobe-spark-page-tutorijal/ (pristupljeno 20.5. 2020.)

Tamilselvan, N., Sivakumar, N., Sevukan, R. (2012) Information and communication technologies (ICT). International journal of library and information science.

UNESCO (2018) ICT Competency Framework for Teachers. Pariz: UNESCO.

Valčić, Jelena (2017) E-laboratorij: LearningApps - jednostavna izrada alata za nastavu. https://e-laboratorij.carnet.hr/learning-apps-jednostavno-izradite-alat-svoju-nastavu/ (Pristupljeno: 20.5. 2020.) 


\title{
Modern information and communication tools in distance learning
}

\author{
Tanja Đurić \\ tanja.duric@skole.hr \\ Osnovna škola Gračani, Zagreb
}

The Croatian educational system has been at a digital crossroads for the last ten years. Projects like CARNET's Škole 2.0. [Schools 2.0] and the Škola za život [School for life] educational reform were the forerunners of this crossroads. The most significant digital change was the rapid and mass introduction of distance or online learning that took place as a result of the coronavirus pandemic and the subsequent lockdown in the 2019/2020 school year. It required teachers to react quickly and use ICT in the learning process. The aim of this paper is to provide an overview of contemporary information tools in distance learning and to investigate which tools were mostly used in primary schools in distance learning. Moreover, foreign language teachers' attitudes in primary schools about the level of accomplished educational outcomes and language skills supported by ICT tools were studied, as well as the advantages and disadvantages teachers were faced with during distance learning. A survey containing 14 questions was used in the study, which included 58 respondents. A combination of quantitative and qualitative analysis was used in the presentation of the study's results, which indicate significant success in distance learning and a great variety of ICT tools used for this purpose.

Keywords: ICT tools, foreign languages, primary school, distance learning 